\title{
Cloning, expression and characterization of a versatile Baeyer-Villiger monooxygenase from Dietzia sp. D5
}

\author{
Serena Bisagni, Rajni Hatti-Kaul and Gashaw Mamo*
}

\begin{abstract}
A novel BVMO encoding gene was identified from a draft genome sequence of a newly isolated strain of Dietzia. Analysis of the protein sequence revealed that it belongs to a group of BVMOs whose most characterized member is cyclopentadecanone monooxygenase (CPDMO). The gene was PCR amplified, cloned and successfully expressed in E. coli. The expressed recombinant enzyme was purified using metal affinity chromatography. Characterization of the purified enzyme revealed that it has a broad substrate scope and oxidized different compounds including substituted and unsubstituted alicyclic, bicyclic-, aliphatic-ketones, ketones with an aromatic moiety, and sulfides. The highest activities were measured for 2- and 3-methylcyclohexanone, phenylacetone, bicyclo-[3.2.0]-hept-2-en-6-one and menthone. The enzyme was optimally active at $\mathrm{pH} 7.5$ and $35^{\circ} \mathrm{C}$, a temperature at which its half-life was about 20 hours. The stability studies have shown that this enzyme is more stable than all other reported BVMOs except the phenylacetone monooxygenase from the thermophilic organism Thermobifida fusca.
\end{abstract}

Keywords: Baeyer-Villiger monooxygenase; Biocatalysis; Enzyme stability; Protein expression

\section{Introduction}

Baeyer-Villiger reaction was discovered more than one hundred years ago and refers to the oxidation of a ketone to a lactone or an ester (Baeyer and Villiger 1899). It is regarded as one of the important reactions in chemical industry and is currently accomplished in organic solvents using peroxyacids as oxidants. However, these compounds are harmful and explosive; hence it is considered that Baeyer-Villiger reaction using these oxidants is problematic and unsafe in large-scale industrial reactions (Stewart 1998). Discovery of enzymes known as Baeyer-Villiger monooxygenases (BVMOs) which are able to catalyze such reactions has led to possible alternative of using them as safe and green catalysts for Baeyer-Villiger reactions. In line with this, in the last fifteen years, more than fifty BVMOs have been cloned and expressed in heterologous systems and a number of other BVMOs have also been directly purified from different wild type microorganisms and characterized (Leisch et al. 2011).

\footnotetext{
* Correspondence: gashaw.mamo@biotek.lu.se

Department of Biotechnology, Center for Chemistry and Chemical Engineering, Lund University, P.O. Box 124, SE-22100 Lund, Sweden
}

BVMOs are flavin-dependent enzymes which require $\mathrm{NADPH}$ for regeneration of FAD and use molecular oxygen as the oxidizing agent. These enzymes are known to catalyze the oxidation of ketones and heteroatoms such as sulphur, nitrogen, boron, phosphorus and selenium (Walsh and Chen 1988). In addition to safety, the use of BVMOs allows to run reactions with high enantio- and regio-specificity, which is often difficult to achieve when chemical catalysts are employed. In applications where the chiral nature of the product is an important factor such as in pharmaceutical industries (Pollard and Woodley 2007; Ramesh 2008), the use of BVMOs is of great interest. However, despite such advantages, the application of BVMOs in industrial processes (Baldwin et al. 2008) is hampered due to lack of robust enzymes, complexity of the reaction processes, such as substrate and product inhibition, and difficult downstream processing. One of the major bottlenecks is the poor stability of BVMOs (Leisch et al. 2011). With the exception of phenylacetone monooxygenase (PAMO) obtained from a strain of the thermophilic bacterium Thermobifida fusca (Fraaije et al. 2005), all the other known BVMOs are not stable and very rapidly lose activity even at room temperature (Völker et al. 2008; 
Rehdorf et al. 2009; Kadow et al. 2012). Moreover, the activity and stability of BVMOs are known to be affected by organic solvents (de Gonzalo et al. 2006; Secundo et al. 2011). More stable BVMOs can be potentially obtained by rigorous protein engineering work, and new enzyme discovery by means of conventional microbial screening or from metagenome libraries and genome sequences.

In this article, we describe the cloning, expression and characterization of a novel BVMO from a strain of Dietzia, an organism previously isolated from a soda lake water sample. Although a number of Dietzia were isolated and reported to have rich oxygenase diversity, there has been no BVMO isolated and characterized from these organisms.

\section{Materials and methods Chemicals}

All chemicals were purchased from Sigma Aldrich (Stockholm, Sweden), Calbiochem (Darmstad, Germany) and VWR (Stockholm, Sweden). All the chemicals for PCR, T4 DNA ligase and FastDigest ${ }^{\oplus}$ restriction enzymes were purchased from Fermentas (St. Leon-Rot, Germany). QIAGEN Plasmid Mini Kit and QIAEX II Gel Extraction Kit were purchased from Qiagen (Sollentuna, Sweden).

\section{Microorganisms and plasmid}

Dietzia sp. D5 isolated in our laboratory is deposited in Culture Collection, University of Göteborg (CCUG 64924), Sweden and its genomic DNA was purified using ZR Fungal/Bacterial DNA MiniPrep (Zymo Research, Irvine, USA). E. coli NovaBlue, BL21(DE3), Rosetta2(DE3) and the plasmids pET-22b(+) were purchased from Novagen (Darmstad, Germany). E. coli BL21-CodonPlus(DE3)RP and ArcticExpress(DE3)-RP cells were purchased from Agilent Technologies (Santa Clara, USA).

\section{Gene analysis and cloning}

The gene encoding the monooxygenase BVMO4 was identified from the draft genome sequence of Dietzia sp. D5 (unpublished data). Identification of ORFs and analysis of the BVMO4 gene and its deduced protein sequence was performed with CLCBio Main Workbench (Aarhus, Denmark) FGENESB (Soft Berry Mount Nysco, USA) and BLASTp at NCBI. The phylogenetic tree was generated using the software FigTree.

The BVMO4 encoding gene was amplified by PCR from Dietzia sp. D5 genomic DNA sample using a pair of primers, forward primer ATTACCATGGCCTTCAC CCTCCCTG and reverse primer ATTAGCGGCCGCG GCCACCGGGACCGCGTCG which have the NcoI and Not $\mathrm{I}$ restriction sites, respectively. The PCR amplification was performed with High Fidelity PCR Enzyme Mix (Fermentas) following the manufacturer protocol but supplemented with $2.5 \%(\mathrm{v} / \mathrm{v})$ DMSO. The PCR product was purified using PCR cleaning kit and digested with NcoI and NotI. The digested DNA was loaded on agarose gel and after electrophoresis it was extracted from the gel using Qiaex II gel extraction kit, and ligated to the expression plasmid pET-22b(+) which was digested using NcoI and NotI. The ligation mix was transformed into competent $E$. coli NovaBlue cells and transferred to ampicillin containing LB-agar plates. After overnight incubation colonies were screened by PCR and plasmids from the insert positive colonies were extracted, sequenced at GATC Biotech AG, Konstanz, Germany and plasmids with correct sequences were transformed to the expression hosts.

\section{Protein expression and purification}

Recombinant E. coli BL21(DE3), Rosetta(DE3), Arctic Express(DE3)-RP and BL21-CodonPlus(DE3)-RP cells were grown in LB medium containing, whenever required, ampicillin $100 \mu \mathrm{g} / \mathrm{ml}$, chloramphenicol $34 \mu \mathrm{g} / \mathrm{ml}$ and gentamycin $20 \mu \mathrm{g} / \mathrm{ml}$, respectively. The cultures were incubated at $30^{\circ} \mathrm{C}$ with shaking $(180 \mathrm{rpm})$, until the $\mathrm{OD}_{600}$ reached 0.6 , then induced with $1 \mathrm{mM}$ IPTG. After overnight induction at $15^{\circ} \mathrm{C}$, the cultures were harvested by centrifugation, resuspended in $20 \mathrm{mM}$ sodium phosphate buffer, $\mathrm{pH} 7.4$ and disrupted by sonication for three rounds of $45 \mathrm{sec}$ burst at $50 \%$ amplitude and $50 \%$ cycle, and $1 \mathrm{~min}$ break. The cell homogenate was centrifuged at $4^{\circ} \mathrm{C}$ for 15 minutes at about $15000 \mathrm{~g}$ using a Sorvall centrifuge and the clear supernatant used as source of the recombinant enzyme.

The His-tagged recombinant enzyme was purified at $4^{\circ} \mathrm{C}$ by Ni-NTA affinity chromatography using HisTrap ${ }^{\text {тм }}$ FF crude column (GE Healthcare, Uppsala, Sweden) following the manufacturer instructions. After elution from the column, the enzyme was desalted and concentrated using Vivaspin 20 MWCO 30,000 centrifugal concentrators (Sartorius Stedim Biotech $\mathrm{GmbH}$, Goettingen, Germany), FAD was added to a final concentration of $10 \mu \mathrm{M}$ and stored at $4^{\circ} \mathrm{C}$ in $50 \mathrm{mM}$ sodium phosphate buffer, pH 7.5. The homogeneity of purified sample was checked using 10\% SDS-PAGE prepared according to Laemmli (Laemmli 1970).

\section{Enzyme assay}

BVMO activity was measured by monitoring the decrease in absorbance of NADPH at $340 \mathrm{~nm}\left(\varepsilon_{\mathrm{NADPH} 340}=\right.$ $6.22 \mathrm{~cm}^{-1} \mathrm{mM}^{-1}$ ) after addition of the substrate. Exceptions were made for 4 ' -hydroxyacetophenone that strongly absorbs at $340 \mathrm{~nm}$ and for which NADPH depletion was measured at $370 \mathrm{~nm}\left(\varepsilon_{\mathrm{NADPH} 370}=2.7 \mathrm{~cm}^{-1} \mathrm{mM}^{-1}\right)$, and ethionamide for which the product formation was measured at $400 \mathrm{~nm}\left(\varepsilon_{\mathrm{ETH} 400}=1.0 \mathrm{~cm}^{-1} \mathrm{mM}^{-1}\right)$ instead of cofactor depletion. All spectrophotometric measurements were made using UV-1650 PC Spectrophotometer (Shimadzu, Kyoto, Japan) at $25^{\circ} \mathrm{C}$, unless otherwise 
mentioned. The reactions were done in $50 \mathrm{mM}$ sodium phosphate buffer $\mathrm{pH} 7.5$, containing $10 \mathrm{mM} \mathrm{KCl}, 60 \mu \mathrm{M}$ $\mathrm{NADPH}$ and $5 \mathrm{mM}$ substrate (except steroids which were used at $0.5 \mathrm{mM}$ due to their low solubility). The final enzyme concentration in the assay was $0.024 \mathrm{mg} / \mathrm{ml}$. Steady state kinetics were measured by varying either the cofactor NADPH or the substrate (phenylacetone or 2-methylcyclohexanone). The kinetic parameters $\left(K_{\mathrm{m}}\right.$ and $\left.k_{\text {cat }}\right)$ of the BVMO were determined using the Lineweaver-Burk plot of the Michaelis-Menten equation under steady-state conditions.

\section{Effect of $\mathrm{pH}$ and temperature on BVMO4 activity and stability}

Effects of $\mathrm{pH}$ and temperature on the enzyme activity were determined by assaying the enzyme at different $\mathrm{pH}$ ( $\mathrm{pH} 5-9)$ and temperatures $\left(10-45^{\circ} \mathrm{C}\right)$. To determine the effect of $\mathrm{pH}$ on the enzyme stability, the enzyme was kept in the buffers at $4^{\circ} \mathrm{C}$ for 24 days and the residual activity was determined. Similarly, thermal stability of BVMO4 was studied by incubating the enzyme at $35^{\circ} \mathrm{C}$ in $50 \mathrm{mM}$ sodium phosphate buffer, $\mathrm{pH} 7.5$ and measuring the residual activity of samples withdrawn periodically. The enzyme solutions used to determine the enzyme stability was $0.5 \mathrm{mg} / \mathrm{ml}$.

\section{Effect of freezing-thawing on BVMO4 activity}

The enzyme solution $(0.5 \mathrm{mg} / \mathrm{ml})$ was subjected to freezethaw cycles in the presence of various cryoprotectants, added at a final concentration: glycerol $20 \%(\mathrm{v} / \mathrm{v})$, sorbitol $1.5 \mathrm{M}$, trehalose $0.5 \mathrm{M}$, betaine $1.5 \mathrm{M}$, DMSO $20 \%$ (v/v), 2-methyl-2,4-pentanediol 20\% (v/v), PEG $60020 \%$ $(\mathrm{w} / \mathrm{v})$, BSA $20 \%(\mathrm{w} / \mathrm{v})$, ectoine $0.5 \mathrm{M}$, hydroxyectoine $0.5 \mathrm{M}$. The enzymatic activity was measured (using phenylacetone as substrate) before freezing and after freezethaw cycles.

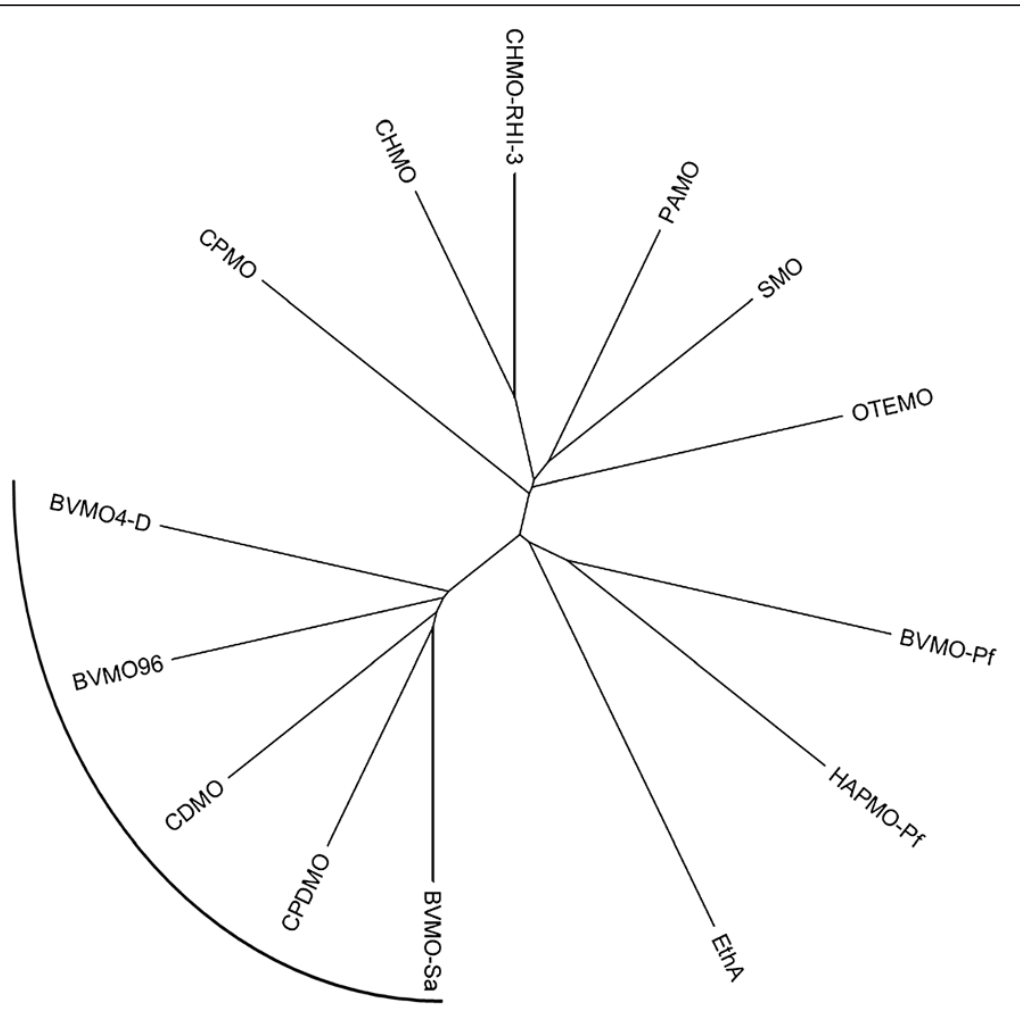

$\overline{0.05}$

Figure 1 A phylogenetic tree of BVMOs. The alignment was done using T-Coffee and the phylogenetic tree was derived using Clustal W2. The BVMOs represented on the tree are: BVMO4 Dietzia sp. D5 (AGY78320.1); BVMO96 Streptomyces coelicolor A3(2) (NP_624628.1); CDMO Rhodococcus ruber SC1 (AAL14233.1); CPDMO Pseudomonas sp. HI-70 (BAE93346.1); BVMO-Sa is BVMO Streptomyces avermitilis MA-4680 (NP_824170.1); EthA is EthA3854C Mycobacterium tuberculosis H37Rv (NP_218371.1); HAPMO-Pf is HAPMO Pseudomonas fluorescens ACB (Q93TJ5.1); BVMO-Pf is BVMO Pseudomonas fluorescens DSM50106 (AAC36351.2); OTEMO Pseudomonas putida (3UOV_A); SMO Rhodococcus rhodochrous (BAF48129.1); PAMO Thermobifida fusca YX (YP_289549.1); CHMO-RHI-3 is CHMO Rhodococcus sp. HI-31 (3UCL_A); CHMO Acinetobacter sp. NCIMB9871 (BAA86293.1); CPMO Comamonas sp. NCIMB9872 (Q8GAW0.3). 

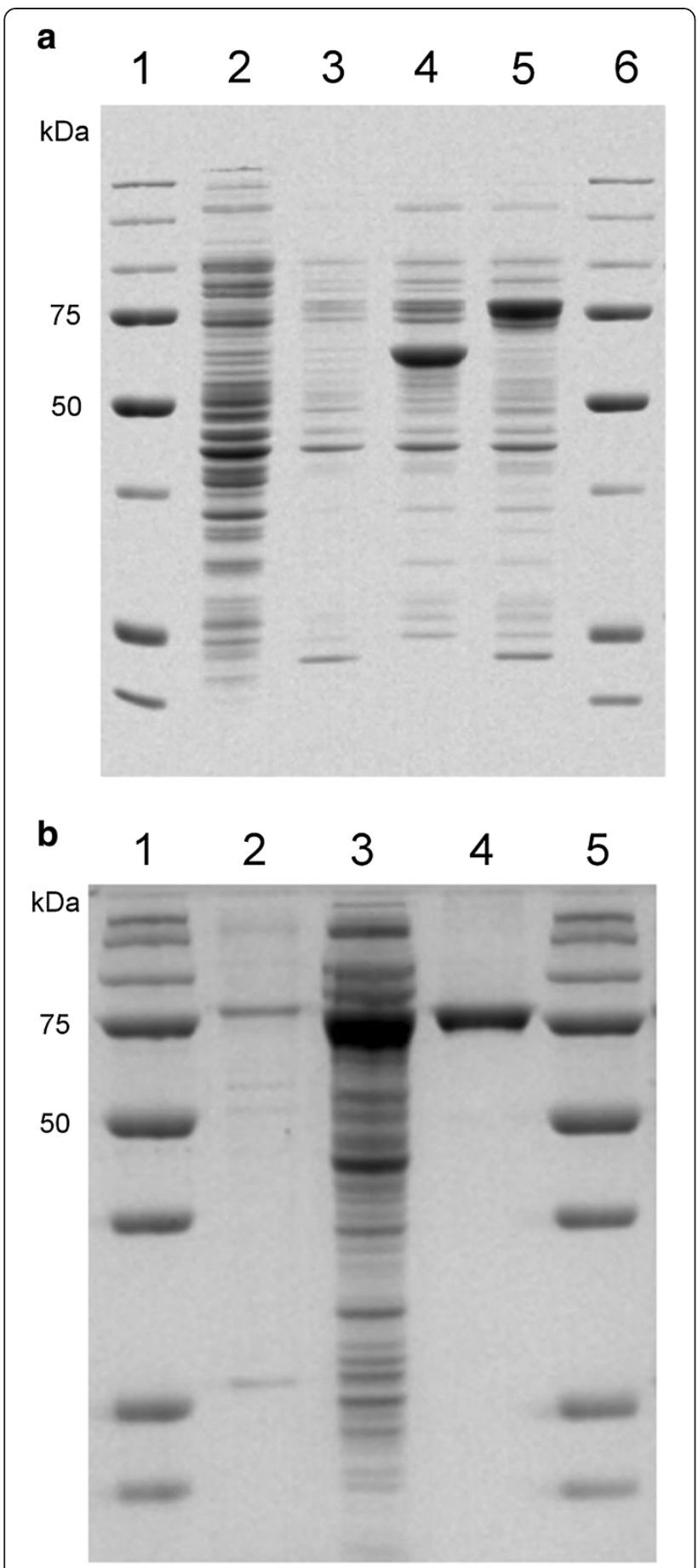

Figure 2 Expression and purification of BVMO4. a) Soluble crude extracts of different E. coli strains expressing BVMO4. Lane 1 and 6, protein marker (AllBlue, BioRad); lane 2, E. coli BL21(DE3); lane 3, E. coli Rosetta(DE3); lane 4, E. coli ArcticExpress(DE3)-RP; and lane 5, E. coli BL21-CodonPlus(DE3)-RP. b) Purified BVMO4. Lane 1 and 5, protein marker (AllBlue, BioRad); lane 2, cell debris; lane 3, soluble cell extract; lane 4, purified protein after His-tag affinity chromatography.

\section{BVMO4 activity in the presence of salt and organic solvents}

To determine salt tolerance, the enzyme activity on phenylacetone was measured at $\mathrm{pH} 7.5$ in the presence of 0-1.2 $\mathrm{M} \mathrm{NaCl}$. Similarly, the effect of organic solvents on the activity of the enzyme was determined by measuring the activity in the presence of $20 \%(\mathrm{v} / \mathrm{v})$ organic solvents.

\section{Nucleic acid sequences}

The nucleic acid and protein sequences reported in this work are available at GenBank under the deposition number KF319017.

\section{Results}

\section{Gene and protein sequence analysis}

The gene encoding BVMO4 was amplified from the genomic DNA of Dietzia sp. D5. The enzyme is composed of 612 amino acids, which makes it larger than most BVMOs which are 500 to 550 amino acids long. BLAST search against database sequences revealed highest identity $(63 \%)$ with the unstudied putative BVMO from Gordonia terrae NBRC 100016 (ZP_09801205), while among characterized BVMOs, $41-44 \%$ sequence similarity was observed with a group of BVMOs whose most studied member is CPDMO and that like BVMO4 are about 600 amino acids long in their primary structure. A phylogenetic tree of BVMO4, CPDMO, CPDMO-like and other known BVMOs is shown in Figure 1.

Comparison of the DNA sequence of the genome fragment of Dietzia sp. D5 containing BVMO4 gene with the recently published genome of a closely related organism, Dietzia cinnamea P4 (Procópio et al. 2012) showed that most of the genes neighboring the BVMO gene are present in the two organisms and have the same order, although two of the predicted ORFs in Dietzia sp. D5 are missing in D. cinnamea P4. The missing ORFs are the ones encoding BVMO4 and a TetR transcriptional regulator gene.

\section{Expression and purification of BVMO4}

E. coli strains BL21(DE3), Rosetta(DE3), ArcticExpress (DE3)-RP and BL21-CodonPlus(DE3)-RP were used to evaluate the expression of BVMO4 in soluble form. The best result was achieved with E. coli BL21-CodonPlus

Table 1 Summary of the recombinant BVMO4 purification steps

\begin{tabular}{lllll}
\hline Steps & $\begin{array}{l}\text { Total } \\
\text { protein }(\mathbf{m g})\end{array}$ & $\begin{array}{l}\text { Total } \\
\text { activity }(\mathbf{U})\end{array}$ & $\begin{array}{l}\text { Specific } \\
\text { activity }(\mathbf{U} / \mathbf{m g})\end{array}$ & $\begin{array}{l}\text { Purification } \\
\text { fold }\end{array}$ \\
\hline $\begin{array}{l}\text { Crude } \\
\text { extract }\end{array}$ & 78.86 & 2.95 & 0.037 & 1 \\
$\begin{array}{l}\text { Purified } \\
\text { enzyme }\end{array}$ & 4.95 & 3.39 & 0.648 & 17.5 \\
\hline
\end{tabular}


(DE3)-RP and SDS-PAGE of the crude cell extract shows a prominent band at about $75 \mathrm{kDa}$ (Figure 2a) which is close to the in silico predicted mass of $72 \mathrm{kDa}$. E. coli BL21(DE3) cells were unable to express BVMO4 while E. coli Rosetta(DE3) and ArcticExpress(DE3)-RP resulted in modest levels of expression; however, the cell growth was considerably lower when compared to BL21CodonPlus(DE3)-RP. Thus, BL21-CodonPlus(DE3)-RP was chosen as the expression host. In the case of $E$. coli ArcticExpress(DE3)-RP the thick protein band at approximately $55 \mathrm{kDa}$ in Figure $2 \mathrm{a}$ is a chaperone that is expressed to help the folding of the BVMO.

The enzyme was purified by His-tag affinity chromatography and the summary of the enzyme purification steps is given in Table 1 . The enzyme lost its activity during the purification process but was recovered upon addition of FAD. The specific activity of the pure enzyme was about $0.65 \mathrm{U} / \mathrm{mg}$ protein when assayed using phenylacetone as substrate.

\section{Effect of $\mathrm{pH}$ and temperature on activity and stability of BVMO4}

Effect of $\mathrm{pH}$ on the activity of the pure enzyme was determined by performing the assay in a $\mathrm{pH}$ range from 5 to 9 . The enzyme was optimally active at $\mathrm{pH} 7.5$ and exhibited more than $50 \%$ of its optimal activity between $\mathrm{pH} 6.5$ and 9.0 (Figure 3a). When stored at $4^{\circ} \mathrm{C}$, the enzyme displayed highest stability in a $\mathrm{pH}$ range of 7.0-8.0 (Figure $3 b$ ).

The enzyme was optimally active at $35^{\circ} \mathrm{C}$ (Figure 4a) and retained about $50 \%$ and $20 \%$ of its initial activity after $20 \mathrm{~h}$ and $48 \mathrm{~h}$ of incubation at $35^{\circ} \mathrm{C}$, respectively (Figure $4 \mathrm{~b})$. The recombinant BVMO can be stored frozen at $-20^{\circ} \mathrm{C}$ for several months without loss of activity.
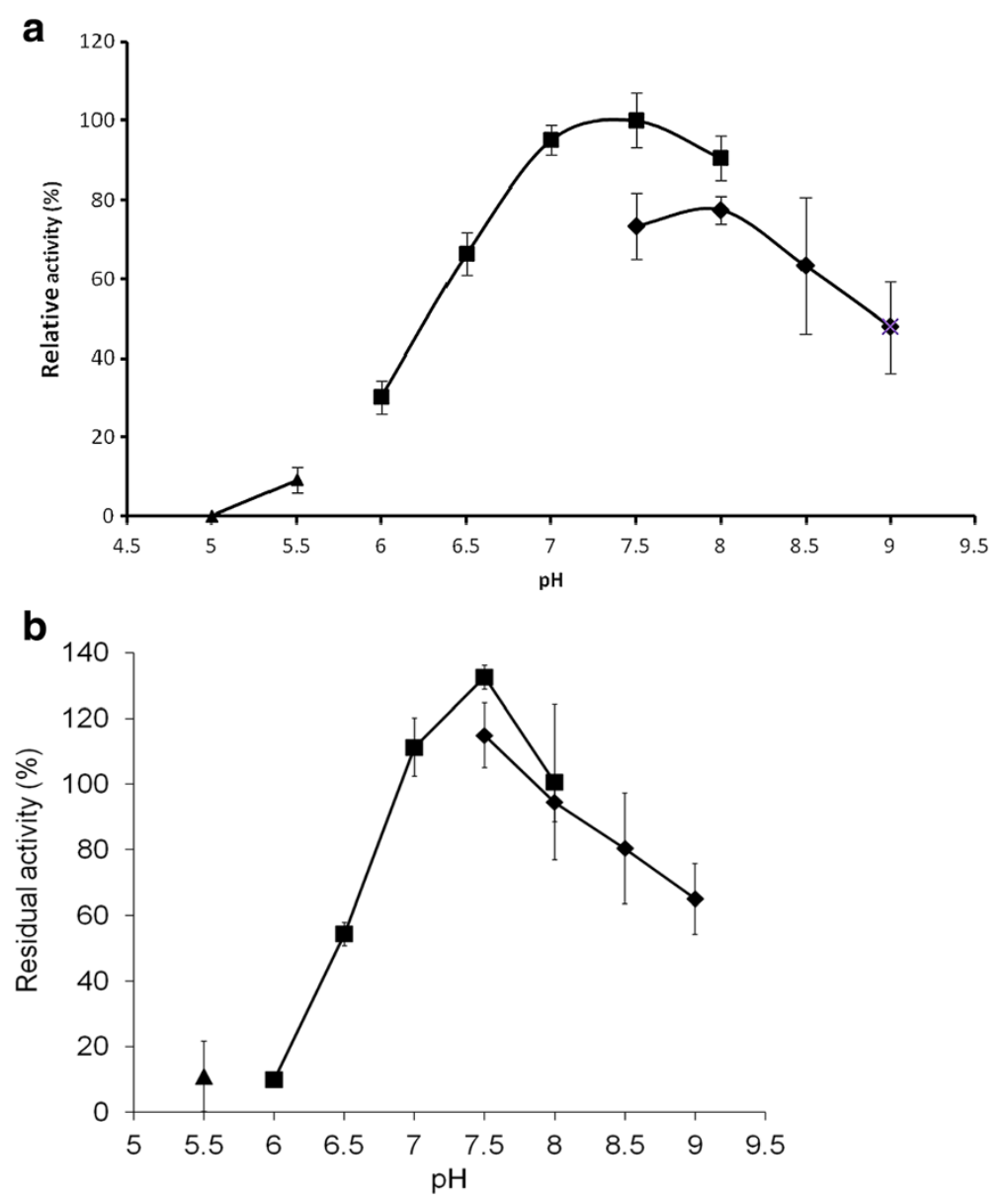

Figure 3 Effect of $\mathbf{p H}$ on activity and stability of BVMO4. a) Effect of $\mathrm{pH}$ on the activity of BVMO4 was determined by assaying the enzyme

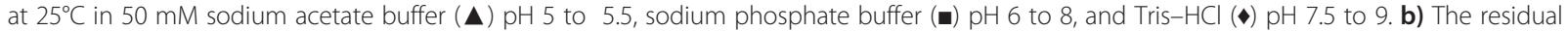
activity of BVMO4 after 24 days at $4{ }^{\circ} \mathrm{C}$ and different pH values was measured at $25^{\circ} \mathrm{C}$ in $50 \mathrm{mM}$ sodium acetate $(\boldsymbol{\Delta})$, sodium phosphate ((-)) and Tris- $\mathrm{HCl}(\bullet)$ buffers. 

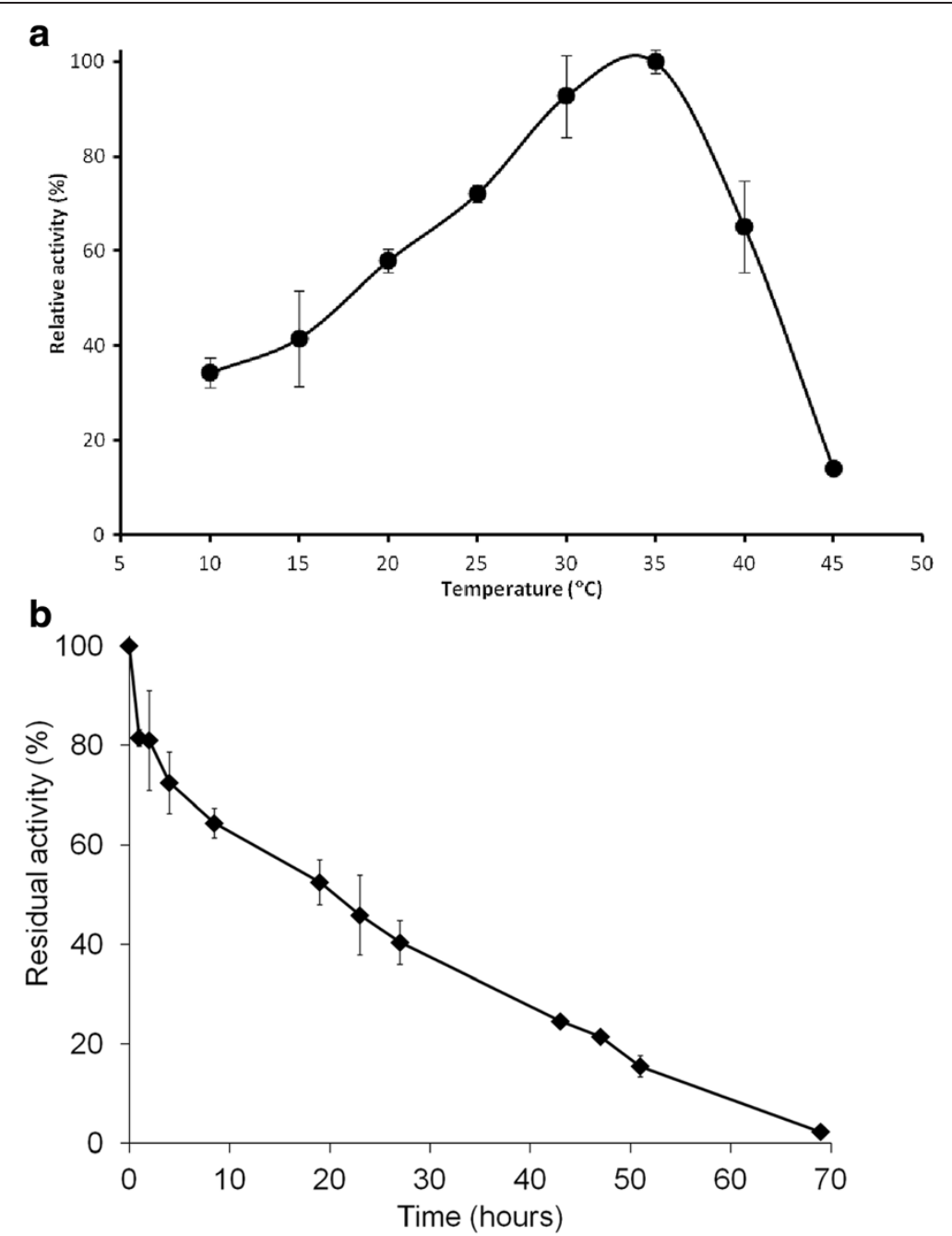

Figure 4 Effect of temperature on activity and stability of BVMO4. a) Effect of temperature on the activity of BVMO4 was determined by assaying the enzyme at different temperatures in $50 \mathrm{mM}$ sodium phosphate buffer, $\mathrm{pH}$ 7.5. b) The BVMO4 stability was studied by incubating the enzyme at $35^{\circ} \mathrm{C}$ in $50 \mathrm{mM}$ sodium phosphate buffer, $\mathrm{pH}$ 7.5. Samples were taken periodically and the residual enzyme activity was determined.

Moreover frozen aliquots of the enzyme proved to be resistant to at least three freeze-thaw cycles both in the presence and absence of cryoprotectants. However, the enzyme lost most of its activity when 2-methyl-2,4pentanediol was used as cryoprotectant (data not shown).

\section{Determination of BVMO4 substrate scope}

A total of 28 compounds were studied as substrates for BVMO4 (Table 2). Activity on phenylacetone was used as a reference (100\%) to determine the relative activity of the enzyme on these different substrates. The highest activity was measured for 2- and 3methylcyclohexanone, phenylacetone, bicyclo[3.2.0]hept2-en-6-one and menthone. It was noted that the position of the methyl substitution in the series of methylcyclohexanones influenced the enzyme activity: 2-methylcyclohexanone had the higher relative activity
(155\%), 3-methylcyclohexanone was a moderately good substrate (90\% relative activity) and 4methylcyclohexanone reacted poorly $(15 \%$ relative activity). Among aliyclic ketones, the highest activity was achieved when cyclohexanone was used as substrate, though they do not appear to be among the best substrates for BVMO4. Aliphatic ketones show approximately the same reactivity as cyclohexanone regardless of the chain length. The enzyme oxidized phenylacetone readily but there was little or no detectable activity when the substrate was a related structure, such as acetophenone and 4 '-hydroxyacetophenone, which indicates the high selectivity of BVMO4 among these substrates. In addition, there was no detectable activity on benzaldehyde. Its activity on sulfides and ketosteroids, was moderate, and the oxidation on the D ring of ketosteroids seems preferred. A detailed study on the activity and enantioselectivity of BVMO4 
Table 2 Relative activity of BVMO4 towards different substrates

\begin{tabular}{|c|c|}
\hline Substrates & Relative acti \\
\hline \multicolumn{2}{|l|}{ Alicyclic ketones } \\
\hline Cyclobutanone & $20.2 \pm 6.1$ \\
\hline Cyclopentanone & $12.7 \pm 5.9$ \\
\hline Cyclohexanone & $22.0 \pm 3.5$ \\
\hline Cycloheptanone & $12.0 \pm 3.6$ \\
\hline Cyclooctanone & $9.3 \pm 3.9$ \\
\hline Cyclopentadecanone & 0.0 \\
\hline \multicolumn{2}{|l|}{ Substituted alicyclic ketones } \\
\hline 2-methylcyclohexanone & $155.3 \pm 24.8$ \\
\hline 3-methylcyclohexanone & $90.5 \pm 1.9$ \\
\hline 4-methylcyclohexanone & $14.6 \pm 0.7$ \\
\hline 2-cyclohexen-1-one & $5.4 \pm 1.1$ \\
\hline \multicolumn{2}{|l|}{ Bicyclic ketones } \\
\hline Bicyclo[3.2.0]hept-2-en-6-one & $103.0 \pm 6.4$ \\
\hline Norcamphor & $6.3 \pm 2.2$ \\
\hline Beta tetralone & 0.0 \\
\hline Alpha tetralone & $10.8 \pm 2.7$ \\
\hline \multicolumn{2}{|l|}{ Aliphatic ketones } \\
\hline 2-heptanone & $20.7 \pm 0.7$ \\
\hline 2-octanone & $22.6 \pm 1.7$ \\
\hline 2-decanone & $22.0 \pm 0.4$ \\
\hline 2-pentadecanone & $20.9 \pm 3.5$ \\
\hline \multicolumn{2}{|c|}{ Aliphatic ketone with aromatic substituents } \\
\hline Phenylacetone & $100.0 \pm 6.2$ \\
\hline Acetophenone & $2.4 \pm 0.8$ \\
\hline 4'-hydroxyacetophenone & 0.0 \\
\hline Benzaldehyde & 0.0 \\
\hline \multicolumn{2}{|l|}{ Sulfides } \\
\hline Thioanisole & $33.0 \pm 13.5$ \\
\hline Ethionamide & $32.0 \pm 1.8$ \\
\hline \multicolumn{2}{|l|}{ Other ketones } \\
\hline Progesterone $e^{a}$ & $23.0 \pm 0.6$ \\
\hline Estrone $^{\mathrm{a}}$ & $17.0 \pm 0.4$ \\
\hline Testosterone $\mathrm{a}^{\mathrm{a}}$ & $6.6 \pm 2.4$ \\
\hline Menthone & $77.1 \pm 2.7$ \\
\hline
\end{tabular}

The activity on phenylacetone which is considered as $100 \%$ was $1.87 \mathrm{mU}$. The

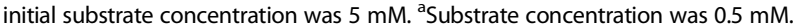

with sulfide and aldehyde substrates has been reported elsewhere (Bisagni et al. 2014).

Steady state kinetic properties of BVMO4 were determined for the cofactor NADPH and two of the best substrates, 2-methylcyclohexanone and phenylacetone (Table 3). The enzyme displayed relatively higher affinity (lower $K_{\mathrm{m}}$ ) for 2-methylcyclohexanone but higher $V_{\max }$ and $k_{\text {cat }}$ for phenylacetone as a result of which $k_{\text {cat }} / K_{\mathrm{m}}$ were similar for the two substrates. The $K_{\mathrm{m}}$ for NADPH was about $10 \mu \mathrm{M}$ while there was no detectable activity when $\mathrm{NADH}$ was used as a cofactor, which indicates that BVMO4 is strictly NADPH dependent.

\section{Enzyme activity in presence of sodium chloride and organic solvents}

Dietzia sp. D5, the source organism for BVMO4, as well as other Dietzia spp., are halotolerant (Plakunov et al. 2008) and hence the salt tolerance of the enzyme was investigated. At $0.4 \mathrm{M} \mathrm{NaCl}$, the enzyme exhibited more than $50 \%$ of the activity in the absence of salt, and the activity decreased steadily with increasing salt concentration up to $1.2 \mathrm{M}$, at which there was no detectable activity (Figure 5a).

The influence of organic solvents frequently used in organic synthesis, on BVMO4 activity was also investigated. The solvents were added to the reaction mixture at a final concentration of $20 \%(\mathrm{v} / \mathrm{v})$. Some activity was detected in the presence of methanol, DMSO and to a lesser extent ethanol but there was no detectable activity in the other solvents tested (Figure 5b).

\section{Discussion}

The sequence similarity analysis of BVMO4 revealed that it is related to a group of Baeyer-Villiger monooxygenases which are characterized by longer amino acid sequences compared to most other BVMOs. The most studied member of this group of BVMOs is CPDMO, a BVMO from Pseudomonas sp. HI-70 (Iwaki et al. 2006; Beneventi et al. 2009; Fink et al. 2011). The other BVMOs belonging to this group are both of microbial and fungal origin (Miyamoto et al. 1995; Jiang et al. 2009; Qiao et al. 2011) and are known to be very versatile in terms of their substrate scope, and efficiently catalyze the oxidation of a wide range of substrates, which indicates a broader application potential (Fink et al. 2012; Bianchi et al. 2013).

Table 3 Steady state kinetic properties of BVMO4

\begin{tabular}{lllll}
\hline & $\boldsymbol{K}_{\mathbf{m}}(\mathbf{m M})$ & $\boldsymbol{V}_{\max }\left(\mathbf{m M ~ s}^{-\mathbf{1}}\right)$ & $\boldsymbol{k}_{\mathrm{cat}}\left(\mathbf{s}^{-\mathbf{1}}\right)$ & $\boldsymbol{k}_{\mathrm{cat}} / \boldsymbol{K}_{\mathbf{m}}\left(\mathbf{m M}^{-\mathbf{1}} \mathbf{s}^{-\mathbf{1}}\right)$ \\
\hline Phenylacetone & $0.829 \pm 0.163$ & $7.90 \mathrm{E}-05 \pm 2.31 \mathrm{E}-06$ & $0.634 \pm 0.104$ & $0.77 \pm 0.03$ \\
2-methylcyclohexanone & $0.507 \pm 0.142$ & $5.11 \mathrm{E}-05 \pm 1.31 \mathrm{E}-05$ & $0.370 \pm 0.095$ & $0.73 \pm 0.02$ \\
NADPH & $0.011 \pm 0.002$ & $7.00 \mathrm{E}-05 \pm 7.80 \mathrm{E}-06$ & $0.507 \pm 0.057$ & $45.06 \pm 1.52$ \\
\hline
\end{tabular}



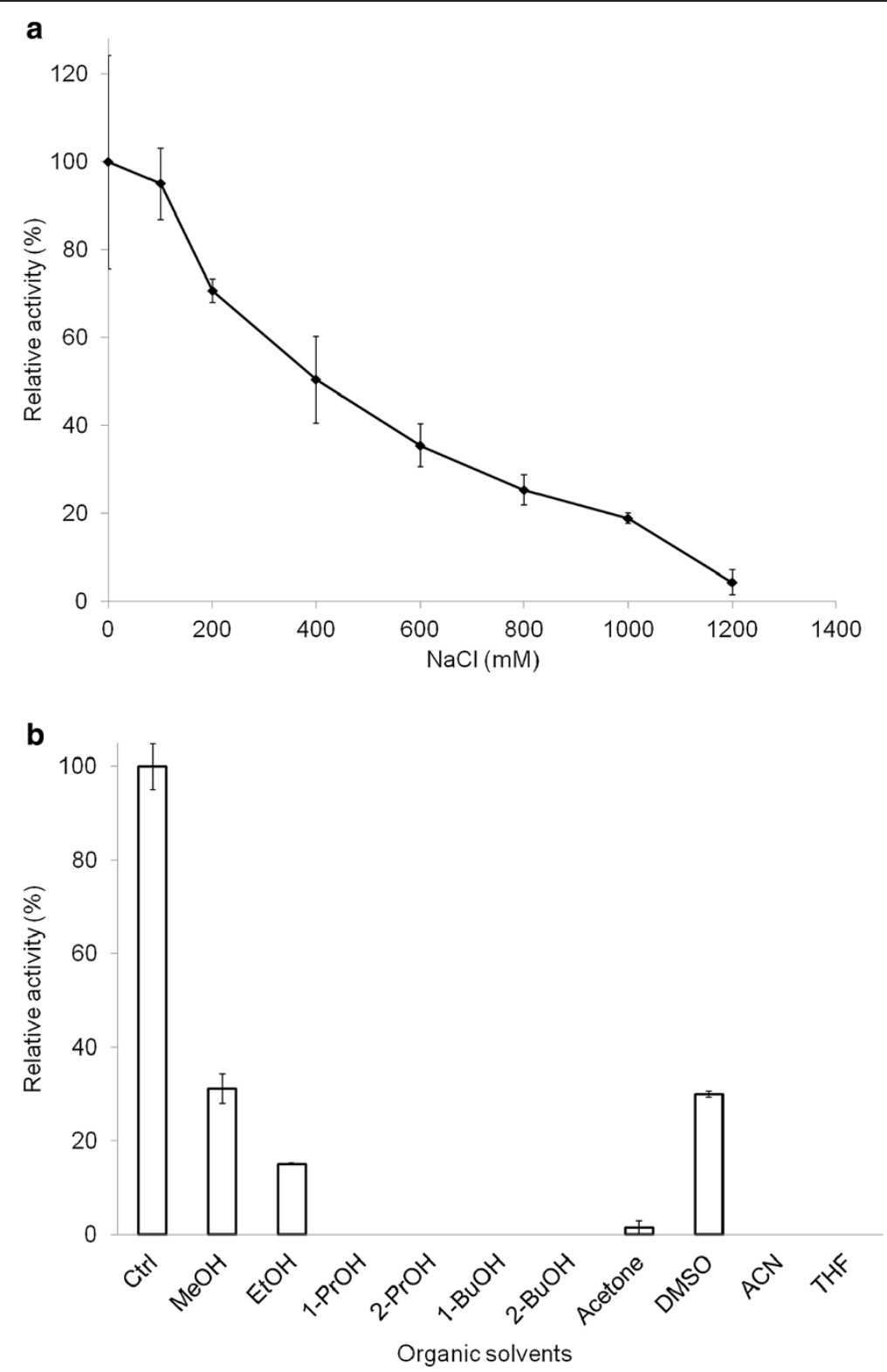

Figure 5 Effect of $\mathrm{NaCl}$ and organic solvents on the activity of BVMO4. a) Activity of BVMO4 in the presence of varying concentration of $\mathrm{NaCl}$. The assay was performed at $25^{\circ} \mathrm{C}$ in $50 \mathrm{mM}$ sodium phosphate buffer, $\mathrm{pH} 7.5$. b) Effect of different organic solvents (20\% v/v) on the activity of BVMO4.

Dietzia spp. genomes have high GC content; in fact the BVMO4 encoding gene has over $67 \%$ GC content and a number of rare codons. Expression of high GC genes containing multiple rare codons in $E$. coli is difficult and most of the commonly used strains such as $E$. coli BL21(DE3) cannot properly express such genes. However, some E. coli strains developed for the expression of this kind of genes are appearing in the market. Among these strains are E. coli Rosetta(DE3), BL21CodonPlus(DE3)-RP and ArcticExpress(DE3)-RP which successfully expressed BVMO4 gene as shown in Figure 2a while expression in BL21(DE3) was not possible. BL21-
CodonPlus(DE3)-RP was better than the other two strains; protein expression is much higher and the culture has grown to cell density comparable to that of BL21(DE3), while the other strains, especially Rosetta(DE3), have a much lower growth rate.

The recombinant BVMO4 expressed in E. coli BL21CodonPlus(DE3)-RP cells was purified to homogeneity by immobilized metal ion affinity chromatography. It was observed that the enzyme completely lost its activity during the purification process. Since the activity of the purified enzyme was recovered with addition of FAD, the loss of activity during purification is believed to be 
due to loss of the cofactor and such phenomenon has been reported before (Nam et al. 2002, Malito et al. 2004). Addition of FAD after the enzyme purification not only restored the activity but also resulted in a higher level of total activity in the purified enzyme than the crude form (Table 1). This might be due to an insufficient production of FAD by the $E$. coli cells, which may result in a part of the expressed enzyme in the crude extract being inactive due to lack of the cofactor. The addition of FAD precursors such as riboflavin, to the reaction media might increase the enzymatic activity in the crude extract (Yoshikane et al. 2004; Wang and Wang 2007).

The optimal $\mathrm{pH}$ for the activity of BVMO4 $(\mathrm{pH} 7.5)$ is slightly lower than the $\mathrm{pH}$ optima of most BVMOs that lies between $\mathrm{pH} 8$ and 9.5. However, it is similar to that of cyclopentanone monooxygenase ( $\mathrm{pH} 7.7)$ from a Pseudomonas strain (Griffin and Trudgill 1976). BVMO4 is less active and less stable in acidic solution which has also been observed for other BVMOs (Secundo et al. 2005; Völker et al. 2008; Rehdorf et al. 2009).

Although several BVMOs are available as recombinant enzymes, they have so far been very seldom used in industrial applications (Baldwin et al. 2008). Poor stability is one of the factors that hindered their applications (Clouthier and Pelletier 2012). A number of purified monooxygenases rapidly lose activity even when stored at $4^{\circ} \mathrm{C}$ or in a frozen state (Völker et al. 2008; Kadow et al. 2012). A CHMO from Acinetobacter, one of the most studied BVMOs, has a half-life of 24 hours at $25^{\circ} \mathrm{C}$ (Zambianchi et al. 2002) and a similar property was observed for a HAPMO (Rehdorf et al. 2009). Another enzyme, OTEMO is totally inactive after 4 hours at $25^{\circ} \mathrm{C}$ and loses half of its initial activity within 24 hours at $4^{\circ} \mathrm{C}$ (Kadow et al. 2012). Interestingly, BVMO4 displayed higher stability than the great majority of BVMOs. Moreover, BVMO4 can be stored and freeze-thawed repeatedly without significant loss of activity.

As applications of BVMOs involve oxidation of organic compounds, it is important to know the effect of organic solvents, such as those used to dissolve substrates, on the enzyme activity. The activity of BVMO4 in the presence of organic solvents at $20 \%(\mathrm{v} / \mathrm{v})$ final concentration was comparable to what has been reported for a CHMO (Secundo et al. 2011) but lower than a PAMO (de Gonzalo et al. 2006, 2012). Similarily, high salt concentration can affect enzyme hydration and enzymes that are stable at high salt concentrations are preferred for industrial applications (Woodley 2013). BVMO4 retained more than $50 \%$ of its salt-free activity at $\mathrm{NaCl}$ concentration of up to $0.4 \mathrm{M}$. Although this concentration does not seem outstandingly high, the enzyme has shown moderate resistance. Such data is however not available for other BVMOs.
BVMO4 has a wide substrate scope and oxidizes substrates with aromatic moiety, substituted cyclic ketones and ketones in multi-ring compounds. In addition, the enzyme oxidized alicyclic and linear aliphatic ketones, thiols and bulky substrates, such as steroids, although at a lower rate. Despite the primary sequence of the enzyme is close to BVMOs belonging to CPDMO group, it poorly oxidizes medium-sized ketones and did not show activity on cyclopentadecanone. Some discrepancies in the enzyme sequence can be the cause for the different affinity for bulky alicyclic ketones. Thus, it can be speculated that BVMO4 is a novel enzyme. In fact, when compared to other BVMOs in the CPDMO group, this enzyme branches out early in the phylogenetic tree (Figure 1). When the kinetic parameters were measured with phenylacetone and 2-methylcyclohexanone as substrates, the $K_{\mathrm{m}}$ values were in the order of hundreds of $\mu \mathrm{M}$ (Table 3 ). The $K_{\mathrm{m}}$ of cyclohexanone for CHMO (Trudgill 1990) is two orders of magnitude lower than the ones measured for BVMO4, indicating that although phenylacetone and 2-methylcyclohexanone are readily oxidized, BVMO4 has relatively low affinity for the substrates.

The results of this study show that BVMO4 is an interesting enzyme to catalyze oxidation of various substrates. In particular, its wide substrate scope and high stability make this enzyme a potential candidate for various Baeyer-Villiger oxidations. Further work to demonstrate its potential on biotransformations of different substrates, understanding its structure-function relationship and improving its property through mutagenesis is currently being considered.

Competing interests

The authors declare that they have no competing interests.

\section{Acknowledgments}

This research was supported by Marie Curie Networks for Initial Training fellowship in the project "BIOTRAINS" (FP7-PEOPLE-ITN-2008-238531).

Received: 7 January 2014 Accepted: 7 January 2014

Published online: 20 March 2014

\section{References}

Baeyer A, Villiger V (1899) Einwirkung des caro'schen reagens auf ketone. Ber der Dtsch Chem Ges 32:3625-3633. doi:10.1002/cber.189903203151

Baldwin CVF, Wohlgemuth R, Woodley JM (2008) The first 200-L scale asymmetric Baeyer-Villiger oxidation using a whole-cell biocatalyst. Org Process Res and Dev 12:660-665. doi:10.1021/op800046t

Beneventi E, Ottolina G, Carrea G, Panzeri W, Fronza G, Lau PCK (2009) Enzymatic Baeyer-Villiger oxidation of steroids with cyclopentadecanone monooxygenase. J of Mol Catal B: Enzym 58:164-168. doi:10.1016/j.molcatb.2008.12.009

Bianchi DA, Moran-Ramallal R, lqbal N, Rudroff F, Mihovilovic MD (2013) Enantiocomplementary access to carba-analogs of $\mathrm{C}$-nucleoside derivatives by recombinant Baeyer-Villiger monooxygenases. Bioorg Med Chem Lett 23:2718-2720. doi:10.1016/j.bmcl.2013.02.085

Bisagni S, Summers B, Kara S, Hatti-Kaul R, Grogan G, Mamo G, Hollmann F (2014) Exploring the substrate specificity and enantioselectivity of a Baeyer-Villiger monooxygenase from Dietzia sp. D5: oxidation of sulfides and aldehydes. Top Catal 57:366-375. doi:10.1007/s11244-013-0192-1 
Clouthier CM, Pelletier JN (2012) Expanding the organic toolbox: a guide to integrating biocatalysis in synthesis. Chem Soc Rev 41:1585-1605. doi:10.1039/c2cs15286j

de Gonzalo G, Ottolina G, Zambianchi F, Fraaije MW, Carrea G (2006) Biocatalytic properties of Baeyer-Villiger monooxygenases in aqueous-organic media. J Mol Catal B: Enzym 39:91-97. doi:10.1016/j.molcatb.2006.01.010

de Gonzalo G, Rodríguez C, Rioz-Martínez A, Gotor V (2012) Improvement of the biocatalytic properties of one phenylacetone monooxygenase mutant in hydrophilic organic solvents. Enzym Microb Technol 50:43-49. doi:10.1016/ j.enzmictec.2011.09.006

Fink MJ, Fischer TC, Rudroff F, Dudek H, Fraaije MW, Mihovilovic MD (2011) Extensive substrate profiling of cyclopentadecanone monooxygenase as Baeyer-Villiger biocatalyst reveals novel regiodivergent oxidations. J Mol Catal B: Enzym 73:9-16. doi:10.1016/j.molcatb.2011.07.003

Fink MJ, Rial DV, Kapitanova P, Lengar A, Rehdorf J, Cheng Q, Rudroff F, Mihovilovic MD (2012) Quantitative comparison of chiral catalysts selectivity and performance: a generic concept illustrated with cyclododecanone monooxygenase as Baeyer-Villiger biocatalyst. Adv Synth Catal 354:3491-3500. doi:10.1002/adsc.201200453

Fraaije MW, Wu J, Heuts DPHM, van Hellemond EW, Spelberg JHL, Janssen DB (2005) Discovery of a thermostable Baeyer-Villiger monooxygenase by genome mining. Appl Microbiol Biotechnol 66:393-400. doi:10.1007/ s00253-004-1749-5

Griffin M, Trudgill PW (1976) Purification and properties of cyclopentanone oxygenase of Pseudomonas NCIB 9872. Eur J Biochem 63:199-209. doi:10.1111/j.1432-1033.1976.tb10222.x

Iwaki H, Wang S, Grosse S, Bergeron H, Nagahashi A, Lertvorachon J, Yang J, Konishi Y, Hasegawa Y, Lau PCK (2006) Pseudomonad cyclopentadecanone monooxygenase displaying an uncommon spectrum of Baeyer-Villiger oxidations of cyclic ketones. Appl Environ Microbiol 72:2707-2720. doi:10.1128/AEM.72.4.2707-2720.2006

Jiang J, Tetzlaff CN, Takamatsu S, Iwatsuki M, Komatsu M, Ikeda H, Cane DE (2009) Genome mining in Streptomyces avermitilis: a biochemical Baeyer-Villiger reaction and discovery of a new branch of the pentalenolactone family tree. Biochem 48:6431-6440. doi:10.1021/bi900766w

Kadow M, Loschinski K, Saß S, Schmidt M, Bornscheuer U (2012) Completing the series of BVMOs involved in camphor metabolism of Pseudomonas putida NCIMB 10007 by identification of the two missing genes, their functional expression in E. coli and biochemical characterization. Appl Microbiol Biotechnol 96:419-429. doi:10.1007/s00253-011-3859-1

Laemmli UK (1970) Cleavage of structural proteins during the assembly of the head of bacteriophage T4. Nature 227:680-685. doi:10.1038/227680a0

Leisch H, Morley K, Lau PCK (2011) Baeyer-Villiger Monooxygenases: more than just green chemistry. Chem Rev 111:4165-4222. doi:10.1021/cr1003437

Malito E, Alfieri A, Fraaije MW, Mattevi A (2004) Crystal structure of a BaeyerVilliger monooxygenase. Proc Natl Acad Sci USA 101:13157-13162. doi:10.1073/pnas.0404538101

Miyamoto M, Matsumoto J, Iwaya T, Itagaki E (1995) Bacterial steroid monooxygenase catalyzing the Baeyer-Villiger oxidation of C21-ketosteroids from Rhodococcus rhodochrous: the isolation and characterization. Biochim Biophys Acta - Prot Struct Mol Enzymol 1251:115-124. doi:10.1016/ 0167-4838(95)00090-H

Nam JW, Nojiri H, Noguchi H, Uchimura H, Yoshida T, Habe H, Yamane H, Omori T (2002) Purification and characterization of carbazole 1,9a-dioxygenase, a three-component dioxygenase system of Pseudomonas resinovorans strain CA10. Appl Environ Microbiol 68:5882-5890. doi:10.1128/AEM.68.12.58825890.2002

Plakunov VK, Zhurina MV, Belyaev SS (2008) Resistance of the oil-oxidizing microorganism Dietzia sp. to hyperosmotic shock in reconstituted biofilms. Microbiol 77:515-522. doi:10.1134/S0026261708050019

Pollard DJ, Woodley JM (2007) Biocatalysis for pharmaceutical intermediates: the future is now. Trends Biotechnol 25:66-73. doi:10.1016/j.tibtech.2006.12.005

Procópio L, Alvarez V, Jurelevicius D, Hansen L, Sørensen S, Cardoso J, Pádula M, Leitão Á, Seldin L, van Elsas J (2012) Insight from the draft genome of Dietzia cinnamea P4 reveals mechanisms of survival in complex tropical soil habitats and biotechnology potential. Antonie Van Leeuwenhoek 101:289-301. doi:10.1007/s10482-011-9633-7

Qiao K, Chooi Y-H, Tang Y (2011) Identification and engineering of the cytochalasin gene cluster from Aspergillus clavatus NRRL 1. Metab Eng 13:723-732. doi:10.1016/j.ymben.2011.09.008
Ramesh NP (2008) Synthesis of chiral pharmaceutical intermediates by biocatalysis. Coord Chem Rev 252:659-701. doi:10.1016/j.ccr.2007.10.031

Rehdorf J, Zimmer CL, Bornscheuer UT (2009) Cloning, expression, characterization, and biocatalytic investigation of the 4-hydroxyacetophenone monooxygenase from Pseudomonas putida JD1. Appl Environ Microbiol 75:3106-3114. doi:10.1128/AEM.02707-08

Secundo F, Fialà S, Fraaije MW, de Gonzalo G, Meli M, Zambianchi F, Ottolina G (2011) Effects of water miscible organic solvents on the activity and conformation of the Baeyer-Villiger monooxygenases from Thermobifida fusca and Acinetobacter calcoaceticus: a comparative study. Biotechnol Bioeng 108:491-499. doi:10.1002/bit.22963

Secundo F, Zambianchi F, Crippa G, Carrea G, Tedeschi G (2005) Comparative study of the properties of wild type and recombinant cyclohexanone monooxygenase, an enzyme of synthetic interest. J Mol Catal B: Enzym 34:1-6. doi:10.1016/j.molcatb.2005.04.001

Stewart JD (1998) Cyclohexanone monooxygenase: a useful asymmetric BaeyerVilliger reactions. Curr Org Chem 2:195-216. doi:10.1002/chin.199844320

Trudgill PW (1990) Cyclohexanone 1,2-monooxygenase from Acinetobacter NCIMB 9871. Methods Enzymol 188:70-77. doi:10.1016/0076-6879(90)88014-2

Völker A, Kirschner A, Bornscheuer U, Altenbuchner J (2008) Functional expression, purification, and characterization of the recombinant BaeyerVilliger monooxygenase MekA from Pseudomonas veronii MEK700. Appl Microbiol Biotechnol 77:1251-1260. doi:10.1007/s00253-007-1264-6

Walsh CT, Chen YCJ (1988) Enzymic Baeyer-Villiger oxidations by flavin-dependent monooxygenases. Angew Chem Int Ed 27:333-343. doi:10.1002/anie.198803331

Wang L, Wang W (2007) Coenzyme precursor-assisted expression of a cholesterol oxidase from Brevibacterium sp. in Escherichia coli. Biotechnol Lett 29:761-766. doi:10.1007/s10529-006-9295-0

Woodley JM (2013) Protein engineering of enzymes for process applications. Curr Opin Chem Biol 17:310-316. doi:10.1016/j.cbpa.2013.03.017

Yoshikane Y, Yokochi N, Ohnishi K, Yagia T (2004) Coenzyme precursor-assisted cooperative overexpression of an active pyridoxine 4-oxidase from Microbacterium luteolum. Prot Expr Purif 34:243-248. doi:10.1016/ j.pep.2003.11.013

Zambianchi F, Pasta P, Carrea G, Colonna S, Gaggero N, Woodley JM (2002) Use of isolated cyclohexanone monooxygenase from recombinant Escherichia coli as a biocatalyst for Baeyer-Villiger and sulfide oxidations. Biotechnol Bioeng 78:489-496. doi:10.1002/bit.10207

doi:10.1186/s13568-014-0023-1

Cite this article as: Bisagni et al:: Cloning, expression and characterization of a versatile Baeyer-Villiger monooxygenase from Dietzia sp. D5. AMB Express 2014 4:23.

\section{Submit your manuscript to a SpringerOpen ${ }^{\odot}$ journal and benefit from:}

- Convenient online submission

- Rigorous peer review

- Immediate publication on acceptance

- Open access: articles freely available online

- High visibility within the field

- Retaining the copyright to your article

Submit your next manuscript at springeropen.com 